\title{
Perancangan dan Pembuatan Meja Kinestetik
}

\author{
Design and Development of Kinesthetic Table
}

\author{
Natalia Hartono, Laurence, Prayoga Nathan Subandi \\ Jurusan Teknik Industri, Universitas Pelita Harapan, Tangerang \\ E-mail: natalia.hartono@uph.edu, laurence.fti@uph.edu,prayoganathan@gmail.com
}

\begin{abstract}
Abstrak
Pembelajaran di Indonesia cenderung menggunakan gaya belajar auditori dan visual. Sedangkan gaya belajar tidak hanya auditori dan visual, ada pula gaya belajar kinestetik. Penelitian sebelumnya menunjukan bahwa anak usia Sekolah Dasar (SD) memiliki kecenderungan lebih mudah belajar dengan gaya belajar kinestetik. Prasarana dan sarana di Indonesia masih kurang dalam mendukung gaya belajar kinestetik, berbeda dengan di luar negeri yang sudah menerapkan gaya belajar kinestetik. Tujuan penelitian ini adalah merancang dan membuat suatu meja kinestetik untuk anak usia SD yang ergonomis. Pengambilan data antropometri dan kuesioner dalam merancang produk ini dilakukan di sebuah SD di Tangerang, Indonesia. Meja yang dirancang dilakukan evaluasi uji coba oleh 40 orang siswa SD tersebut. Meja kinestetik berhasil dibuat berdasarkan tahapan perancangan produk Ulrich dan Eppinger (2016). Saat ini, produk sedang dalam tahap pengajuan Hak Desain Industri melalui LPPM Universitas Pelita Harapan.
\end{abstract}

Kata Kunci: ergonomi, gaya belajar, kinestetik, meja

\begin{abstract}
In Indonesia, the education learning style in the classroom was mainly focusing on auditory and visual learners. However, students learning style is not only auditory and visual, but there is also another learning style such as kinesthetic. Previous studies show that children in elementary school tend to learn using kinesthetic learning style. Teaching facilities in Indonesia is a lack of supporting this kind of learning style, compared to other countries. The purpose of this study is to design and made an ergonomic kinesthetic table for elementary school students. An elementary school in Tangerang, Indonesia used as an object to do the research. Anthropometric data and questionnaire were taken there. Evaluation and trial of the prototype by 40 primary students were done in that school. The kinesthetic table was successfully made using Ulrich and Eppinger' product design process. The table is in the process of registering for Intellectual Property Rights through LPPM University of Pelita Harapan.
\end{abstract}

Keywords: ergonomics, learning style, kinesthetic, table

\section{Pendahuluan}

Kecerdasan, menurut Kamus Besar Bahasa Indonesia (KBBI) adalah sempurna perkembangan akal budi seorang manusia untuk berpikir, mengerti, tajam pikiran dan sempurna pertumbuhan tubuhnya (KBBI, n.d). Howard Gardner adalah seorang Professor dari Harvard yang pertama kali mengembangkan teori multiple intelligence di tahun 1983 dimana ia mengidentifikasi 7 kecerdasan manusia, dan kemudian di tahun 1999 menambahkan 2 kecerdasan pada teorinya. Teori tersebut mengatakan ada 9 kecerdasan, yaitu kecerdasan verbal/linguistic, kecerdasan matematis/logika, kecerdasan visual/spasial, kecerdasaan bodily/kinestetik, kecerdasan musical/ritmik, kecerdasan interpersonal, kecerdasan intrapersonal, kecerdasan naturalis dan kecerdasan existential (Chen dkk, 2009). Hasil dari berbagai penelitian masih menunjukan perdebatan antara apakah pembagian steoreotip anak berdasarkan gaya belajar mempengaruhi cara mereka menyerap informasi. Penelitian Rahman dan Ahmar di tahun 2017 untuk siswa SMA di Indonesia juga menyebutkan tidak ada hubungan antara gaya belajar, gender dan interaksi keduanya dalam pencapaian belajar sedangkan penelitian yang dilakukan oleh Vaishnav di India untuk siswa kelas 9, 10, 11 
menunjukan ada korelasi yang tinggi antara gaya belajar kinestetik dengan pencapaian akademik yang baik (Rahman, 2017, Vaishnav, 2013).

Saat ini, di Indonesia, tipe pembelajaran yang mendapat porsi terbesar adalah untuk meningkatkan kecerdasan matematis/logika padahal setiap manusia memiliki kecerdasan yang berbeda dan gaya belajar yang berbeda. Kecerdasan kinestetik seringkali disebut sebagai kecerdasan tubuh (jasmani) dimana anak yang memiliki kecerdasan kinestetik dapat dilihat sebagai anak yang hiperaktif dan tertarik terhadap hal-hal yang berhubungan dengan latihan fisik. Anak yang memiliki kecerdasan kinestetik juga dapat fokus terhadap suatu pelajaran apabila anak tersebut melakukan gerakangerakan tertentu secara tidak sadar sehingga dapat mengurangi rasa stress dan meningkatkan konsentrasi. Sadar akan kecerdasan kinestetik banyak perusahaan berusaha untuk menciptakan alat yang dapat melatih kecerdasan kinestetik seperrti fidget spinner dan fidget cube yang diklaim dapat meningkatkan kemampuan belajar dan menekan tingkat stress seseorang.

Meskipun anak menggunakan semua indra mereka dalam belajar, tetapi ada kecenderungan tertentu dimana mereka belajar dengan baik dengan gaya belajar tertentu (Gilakjani, 2011). Gaya belajar kinestetik lebih banyak dilakukan di luar Indonesia, dimana berfokus pada kegiatan kelas yang berhubungan dengan kegiatan fisik (Begel, 2004). Penelitian Leasa dkk menunjukan bahwa pada tingkat pendidikan dasar, siswa cenderung belajar dengan gaya belajar kinestetik, tingkat pendidikan yang lebih tinggi cenderung belajar menggunakan gaya belajar visual, sementara tingkat pendidikan universitas, menggunakan gaya belajar multimodal (Leasa, 2017).

Penelitian ini akan berfokus pada bagaimana agar gaya belajar kinestetik untuk pembelajaran di kelas untuk anak SD di Indonesia dapat dilakukan. Hal ini didukung dengan penelitian Leasa dkk (2017) yang menyebutkan anak usia SD di Indonesia cenderung belajar dengan gaya kinestetik. Secara umum dapat dilihat pada sekolah SD, banyak anak yang suka bergerak dan berlari, dimana di tingkat lebih tinggi, sudah berkurang jumlahnya.

Hasil penelusuran menunjukan untuk pembelajaran kinestetik, meja kinestetik adalah produk yang dapat dieksplorasi kegunaannya dibandingkan mengubah hal lain dalam kelas untuk gaya belajar kinestetik. Meja kinestetik di luar negeri ada berbagai macam dan dari hasil penelusuran dapat dilihat ada beberapa tipe gerakan dan akan dibahas lebih lanjut di pengolahan data kompetitor. Berdasarkan pencarian di website Direktorat Jendral Kekayaan Intelektual (DJKI) dan dari $e$ commerce di Indonesia, baru ada satu meja kinestetik yang dijual di Indonesia. Meja tersebut terbuat dari plat besi yang dapat disesuaikan tingginya dari $60 \mathrm{~cm}$ hingga $100 \mathrm{~cm}$.

Berdasarkan latar belakang tersebut, penelitian ini melihat bahwa kurangnya sarana prasarana dalam mendukung pembelajaran anak usia SD yang cenderung memiliki gaya belajar kinestetik. Padahal peluang pasar untuk meja belajar kinestetik cukup besar karena baru ada satu meja kinestetik yang dijual di Indonesia. Tujuan penelitian ini adalah merancang suatu meja kinestetik yang ergonomis untuk anak SD. Responden siswa SD dalam penelitian ini adalah siswa kelas empat sampai kelas enam karena mereka lebih dapat memahami pertanyaan yang dibutuhkan dalam penelitian ini. Meja kinestetik ini direncanakan untuk dapat diajukan untuk mendapatkan hak desain industri dan dapat diproduksi untuk dijual. Penelitian ini akan mengambil data di sebuah SD di Tangerang.

\section{Tinjauan Pustaka}

Perancangan dan pengembangan produk oleh Ulrich dan Eppinger (2016) dibagi menjadi 5 tahapan, yaitu tahap concept development, system level design, detail design, testing and refinement, dan productions ramp-up. Merancang produk merupakan prasyarat untuk produksi. Hasil keputusan desain produk selanjutnya diteruskan ke bagian operasi sebagai spesifikasi produksi, guna merumuskan karakteristik produk dan memungkinkan pelaksanaan produksi (Dudung, 2012). Menurut Nasution (2008), banyak konsep atau metode yang dapat diterapkan pada perancangan dan pengembangan produk seperti contoh metode Quality Function Deployment 
(Nasution, 2008). Konsep ini dibangun serta dikembangkan guna untuk menjamin bahwa produk yang memasuki tahapan produksi benar-benar akan dapat memuaskan kebutuhan pelanggan, dengan jalan membentuk tingkat kualitas yang diperlukan dan kesesuaian yang maksimum pada setiap tahap pengembangan.

Kreatifitas merupakan bagian terpenting pada perancangan, karena di dalam perancangan dibutuhkan kreatif, baik dari segi individu ataupun kelompok, kreativitas disini merupakan suatu proses yang menghasilkan sesuatu yang baru. Kreatifitas ditinjau dari segi individu merupakan ungkapan unik dari seluruh pribadi sebagai hasil interaksi individu, perasaan, sikap dan perilakunya (Ginting, 2010).

Merancang produk yang memiliki nilai guna dan membantu mempermudah kehidupan pengguna sangat diperlukan, terutama produk-produk yang ergonomis. Perancangan dan pengembangan produk menjadi suatu bagian dari proses inovasi, untuk itu diharapkan dapat menghasilkan inovasiinovasi produk yang mampu memberikan keunggulan tertentu sehingga bisa mengatasi persaingan produk (Kotler, 2018). Perancangan dan pengembangan produk adalah semua proses yang berhubungan dengan keberadaan produk yang meliputi segala aktifitas mulai dari identifikasi konsumen sampai pada pabrikasi, penjualan dan delivery dari produk. Proses pengembangan merupakan urutan dari langkah-langkah transformasi sebuah input menjadi output sehingga proses tersebut merupakan urutan serta langkah-langkah perusahaan untuk menyusun, merancang dan mengkomersialkan suatu produk (Kotler, 2018).

Desain merupakan suatu proses yang dapat dikatakan seumur dengan keberadaan manusia di dunia. Hal ini sering kali tidak kita sadari. Akibatnya sebagian dari yang berada di dunia berpendapat desain baru dikenal sejak masa modern serta merupakan bagian dari kehidupan modern. Istilah desain secara umum dapat berarti potongan, model, modal, bentuk, pola, konstruksi, serta rencana yang mempunyai maksud (Tahid, 2007). Desain produk merupakan hal yang sangat penting dalam menjaga kelangsungan hidup perusahaan, berbagai desain produk baru diciptakan karena orang percaya bahwa ada kebutuhan akan produk tersebut (Ginting, 2010).

Ergonomi berasal dari kata yunani yaitu Ergo yang berarti kerja dan Nomos yang berarti hukum, dengan demikian ergonomi dimaksudkan sebagai disiplin keilmuan yang mempelajari manusia dalam kaitannya dengan pekerjaan (International Ergonomics Association / IEA). Disiplin ergonomi secara khusus akan mempelajari keterbatasan dari kemampuan manusia dalam berinteraksi dengan teknologi dan produk-produk buatannya (Wignjosoebroto, 2008).

Kecerdasan majemuk adalah teori yang dicetuskan oleh Howard Gardner di tahun 1992 untuk menunjukkan bahwa pada dasarnya setiap individu memiliki banyak kecerdasan. Kecerdasan adalah kemampuan individu dalam menyerap, mengolah dan memecahkan masalah (Chen, Moran dan Gardner, 2009). Adapun kecerdasan-kecerdasan tersebut yaitu:

a. Kecerdasan linguistik adalah kemampuan untuk menggunakan dan mengolah kata-kata secara efektif, baik secara verbal maupun tertulis.

b. Kecerdasan matematis-logis adalah kemampuan untuk menangani bilangan dan perhitungan, pola serta pemikiran logis dan ikniah.

c. Kecerdasan ruang-spasial adalah kemampuan untuk menangkap dunia ruang-spasial secara tepat.

d. Kecerdasan musikal adalah kemampuan untuk mengembangkan, mengekspresikan dan menikmati bentuk-bentuk musik dan suara.

e. Kecerdasan kinestetik-jasmani adalah kemampuan menggunakan tubuh atau gerak tubuh untuk mengekspresikan gagasan atau perasaan.

f. Kecerdasan interpersonal adalah kemampuan untuk mengerti dan peka terhadap perasaan, intensi, motivasi, watak dan temperamen orang lain.

g. Kecerdasan intrapersonal adalah kemampuan yang berkaitan dengan pengetahuan akan diri sendiri dan kemampuan untuk bertindak secara adaptatif berdasarkan pengenalan diri itu.

h. Kecerdasan naturalis adalah kemampuan untuk mengerti alam lingkungan dengan baik, 
dapat membuat distingsi konsekuensial lain dalam alam natural, kemampuan untuk memahami dan menikmati alam dan menggunakan kemampuan tersebut secara produktif.

i. Kecerdasan eksistensial adalah kepekaan atau kemampuan untuk menjawab persoalanpersoalan terdalam eksistensi manusia.

Fleming dan Mills (1992) menyatakan bahwa terdapat empat gaya belajar yaitu, visual, auditory, read/write, dan kinesthetic. Gaya belajar setiap orang tentu berbeda maka gaya belajar dibagi menjadi 3 jenis yakni, gaya belajar visual, gaya belajar auditori, dan gaya belajar kinestetik. Gaya belajar visual adalah gaya belajar dimana anak lebih cepat menyerap pelajaran bila diberikan hal yang berkaitan dengan warna, gambar, atau visual. Gaya belajar auditori adalah gaya belajar anak dimana anak lebih cepat menyerap pelajaran melalui apa yang didengarkan. Gaya belajar kinestetik adalah gaya belajar dimana anak lebih dapat menyerap pelajaran bila melakukan gerakan-gerakan tertentu.

\section{Pembahasan}

Tahap perancangan dan pengembangan produk meja akan mengikuti teori dan langkah dari Ulrich dan Eppinger (2016) dengan fokus pada perancangan meja kinestetik yang ergonomis untuk anak SD. Tahapan langkah perancangan dan pengembangan produk Ulrich dan Eppinger dapat digunakan baik produk yang rumit maupun sederhana (Laurence dkk, 2018) dan berhasil dalam merancang dan mengembangkan berbagai jenis produk seperti meja ramah lingkungan (Hartono dkk, 2018), furnitur (Hartono, 2019), dan pemotong daging ayam (Laurence dkk, 2018). Pengambilan data dilakukan di SD di Tangerang dengan mengambil data antropometri berupa tinggi, tinggi duduk, jangkauan tangan, dan data lainnya pada 40 siswa kelas empat hingga enam. Selain itu, pengambilan data lainnya adalah pengambilan data produk yang dibuat kompetitor baik di Indonesia maupun di luar negeri karena di Indonesia hanya ada satu meja kinestetik. Data tersebut kemudian digunakan sebagai dasar untuk membuat rancangan meja kinestetik yang ergonomis untuk anak SD di Indonesia. Produk meja akan dibuat mulai dari prototype alpha, beta dan produk akhir, dilanjutkan dengan evaluasi produk meja kepada responden anak SD.

Tahap pertama adalah tahap perencanaan dan perancangan produk meja kinestetik dimulai dari identifikasi peluang. Meja kinestetik menjadi suatu peluang pasar baru karena hanya terdapat satu buah meja kinestetik di Indonesia sedangkan di luar negeri seperti di Amerika terdapat berbagai macam jenis produk meja kinestetik yang dipasarkan. Hal ini yang menjadi dasar mengapa meja kinestetik memiliki peluang untuk dikembangkan dan digunakan sebagai alat bantu pendidikan di dalam negeri. Peluang meja kinestetik ini didasari pada penelitian terhadap gaya belajar anak, terdapat tiga gaya belajar anak, ada gaya belajar auditori yakni anak lebih tangkap dalam belajar hanya dengan mendengar, ada gaya belajar visual dimana anak lebih tangkap dalam belajar dengan melihat, dan ada gaya belajar kinestetik dimana anak mampu belajar jika melakukan gerakangerakan tertentu yang merangsang daya tangkap otak. Berdasarkan langkanya meja kinestetik di Indonesia dan hasil penelitian yang menunjukan gaya belajar anak SD cenderung kinestetik, munculah ide untuk mengembangkan meja kinestetik untuk membantu anak dalam belajar sesuai gaya belajar. Meja kinestetik sebenarnya sudah cukup lama ada, tetapi untuk pasar Indonesia masih belum berkembang dengan berbagai macam faktor seperti harganya yang relatif mahal dan kurangnya pengertian terhadap masyarakat akan gaya belajar masing-masing anak. Hasil wawancara dan diskusi dengan guru dan siswa mengerucut pada pemilihan pengembangan di bagian kaki. Karena itu, produk meja kinestetik yang akan dikembangkan akan berfokus pada bagian kaki dengan melakukan uji coba terhadap beberapa mekanisme pedal kaki. Tahapan ini diakhiri dengan membuat kalimat tujuan yang berasal dari identifikasi peluang yang sebelumnya telah dilakukan. Hal ini dilakukan dengan membuat mission statement yang terdiri dari product description, core benefit proposition, key business goal, target market, assumptions and constraints, dan stakeholders (Ulrich dan Eppinger, 2016). Meja belajar kinestetik berbahan kayu dan besi yang ergonomis dan memiliki nilai estetika dengan core benefit proposition agar meningkatkan daya belajar anak, key business goal adalah produk meja dapat terealisasi di Desember 2019, mendapakan Hak Kekayaan Intelektual dan dapat diproduksi secara masal, target 
pasar adalah orang tua siswa usia SD dan sekolah SD, asumsi dan batasan adalah meja kinestetik fokus pada desain bagian kaki, stakeholder adalah Universitas Pelita Harapan sebagai pendana dan pemilik Hak Cipta dan pendesain meja ini. Segmentasi pasar untuk produk ini dibagi menjadi pasar primer yakni anak usia sekolah dasar dan pasar sekunder untuk semua kalangan masyarakat. Pasar primer merupakan target utama produk yang dirancang yakni siswa sekolah dasar. Hal ini dikarenakan masa produktif belajar anak berada di masa sekolah dasar dan anak sekolah dasar ratarata aktif bergerak. Pasar sekunder meja kinestetik ini adalah semua kalangan masyarakat karena meja ini dapat digunakan untuk anak-anak dirumah.

Tahapan kedua adalah tahap pengembangan konsep (concept development). Tahapan ini merupakan pengembangan konsep-konsep yang terdiri dari beberapa faktor seperti identifikasi produk kompetitor, generasi konsep, pemilihan dan pengujian konsep. Tahapan ini diharapkan dapat membangun dan memberikan nilai tambah produk yang akan dibuat berdasarkan peluang pasar dan tetap mengutamakan fungsi kinestetik meja. Analisis kompetitor dilakukan untuk melihat kekuatan dan kelemahan produk kompetitor yang memiliki kesamaan fungsi dengan produk yang akan dirancang. Hal ini akan menjadi tolak ukur dalam pengembangan konsep produk yang akan di rancang. Dalam menganalisis kompetitor diutamakan untuk mempertahankan kelebihan yang dimiliki produk kompetitor dan tidak melihat kelemahan yang dimiliki kompetitor dalam mengembangkan produk yang akan dibuat, sehingga produk dapat memiliki nilai jual yang lebih terhadap pasar. Seperti yang telah dijelaskan di bagian pendahuluan, di Indonesia hanya ada satu meja yang dijual sehingga kompetitor utama hanya satu meja tersebut. Meja yang dijual di luar negeri menjadi acuan sebagai kompetitor lainnya dan rancangan harus berbeda dengan produk yang telah ada sebelumnya. Setelah melakukan analisis kompetitor, dilakukan tahap generasi konsep produk meja kinestetik. Langkah pertama yang dilakukan adalah clarify the problem. Tahap pertama dalam menentukan konsep produk meja adalah mengetahui apa saja masalah yang dialami oleh anak sekolah dasar dalam proses belajar. Selain itu, dilakukan pencarian apakah sudah ada produk sejenis secara eksternal dan internal. Pencarian eksternal dilakukan dengan mencari paten desain meja untuk mengetahui apakah sudah ada konsep yang serupa. Pencarian paten dilakukan dengan menelusuri website Direktorat Jendral Kekayaan Intelektual (DJKI, 2018). Pencarian secara internal dilakukan dengan cara brainstorming dan melihat desain meja belajar yang ada di toko fisik dan toko online. Dari analisis kompetitor yang ada, produk yang dibuat akan dikembangkan dengan memberikan fitur-fitur yang belum ada di pasaran. Material untuk meja dipilih rangka besi agar tahan lama dan kayu karena berdasarkan perhitungan metode Environmental Priority Strategies (EPS), bahan kayu tidak memiliki dampak merusak lingkungan (IVL Swedish Environmental Research Institute, n.d.). Matriks konsep meja dibuat untuk membantu dalam membuat beberapa desain alternatif yang dapat dilihat pada Gambar 1. Desain alternatif difokuskan pada bagian kinestetik di bagian kaki meja berdasarkan hasil wawancara dengan guru dan siswa. 


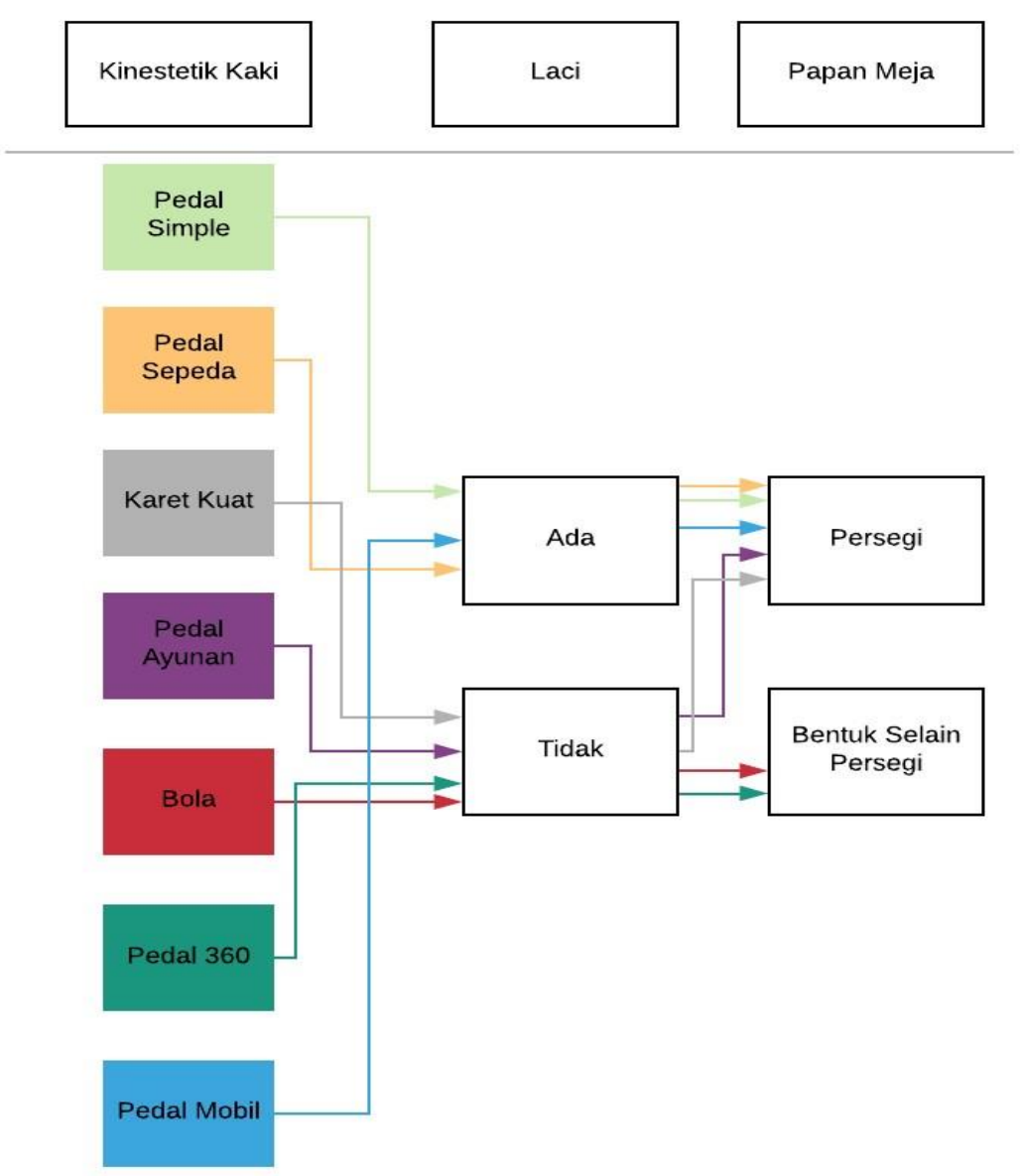

Gambar 1. Matriks Konsep Meja

Sumber: Penulis, 2020

Matriks konsep meja ini menunjukkan bahwa terdapat 7 konsep desain alternatif produk meja yang akan dibuat. Konsep pertama berwarna hijau, konsep kedua berwarna oranye, konsep ketiga berwarna abu-abu, konsep keempat berwarna ungu, konsep kelima berwarna merah, konsep keenam berwarna hijau, konsep ketujuh berwarna biru. Gambar 2 adalah konsep pertama (Desain A) yang menggunakan mekanisme pedal sederhana yang dihubungkan dengan 2 buah bearing sehingga dapat berputar 360 derajat. Pedal yang digunakan dibuat dengan cara memotong besi-besi dengan ukuran yang telah ditentukan dan kemudian dilas dengan rapih. Papan meja yang digunakkan akan terbuat dari kayu. Rangka meja konsep 1 ini menggunakan besi untuk meningkatkan durabilitas meja.

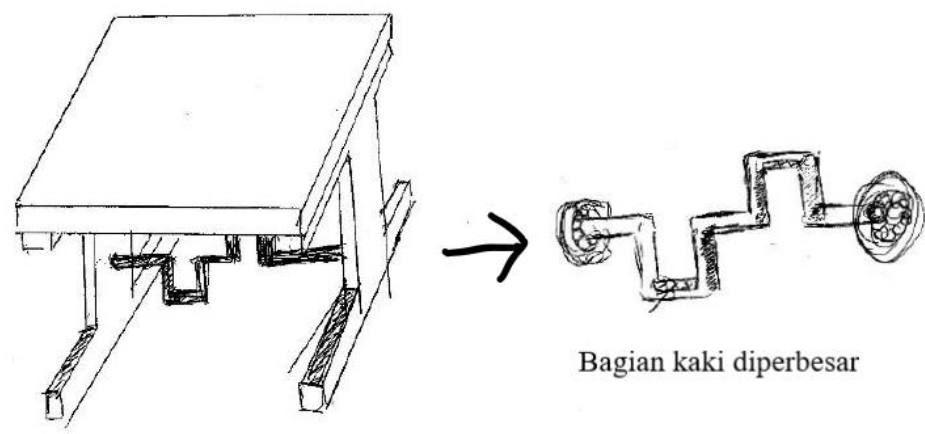

Gambar 2. Konsep Pertama (Desain A) Sumber: Penulis, 2020 
Konsep kedua (Desain B) mengambil ide dengan menggabungkan sepeda dengan meja yang dapat dilihat pada Gambar 3. Meja ini memiliki pedal sepeda yang akan disambungkan pada satu bearing sehingga dapat menekan suara berisik ketika dikayuh. Sama seperti konsep 1 pedal sepeda dibuat dari besi yang dipotong dengan ukuran yang telah ditentukan dan dilas. Meja ini menggunakan rangka yang dapat diatur (adjustable) ketinggiannya dan mudah untuk dipindahkan kemana-mana.

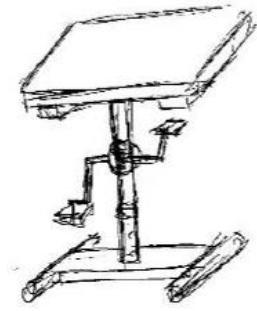

Gambar 3. Konsep Kedua (Desain B)

Sumber: Penulis, 2020

Konsep ketiga (Desain C) pada Gambar 4 menggunakan karet di bagian bawah papan meja dengan cara dibaut. Karet memiliki kelenturan dan kekuatan yang cukup baik ketika diberikan gaya tarik yang besar. Rangka meja menggunakan besi untuk meningkatkan durabilitas meja, dan papan meja menggunakan bahan kayu.

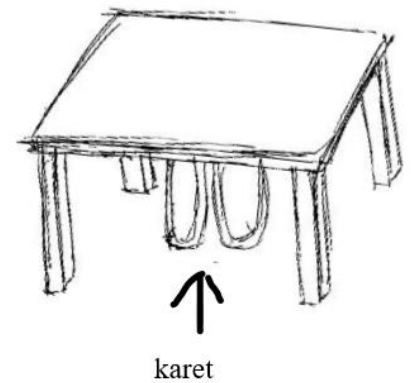

Gambar 4. Konsep Ketiga (Desain C) Sumber: Penulis, 2020

Konsep keempat (Desain D) menggunakan pedal kayuh yang dapat dilihat pada Gambar 5 . Mekanisme kinestetik menggunakan pedal yang dapat diayun 180 derajat, kedua pedal tersebut dipasangkan pada satu batang yang telah tersambung dengan 2 buah bearing pada kedua ujung rangka meja sehingga meningkatkan durabilitas mekanisme itu sendiri. Rangka meja masih menggunakan besi dan papan meja menggunakan bahan kayu.

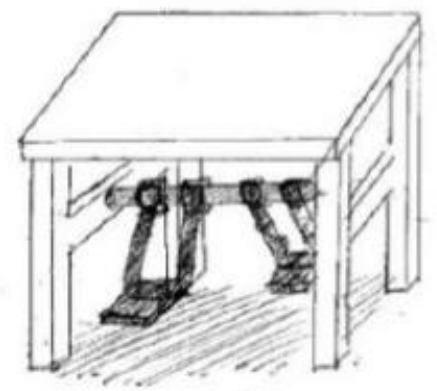

Gambar 5. Konsep Keempat (Desain D) Sumber: Penulis, 2020

Gambar 6 adalah konsep alternatif kelima (Desain E). Mekanisme kinestetik yang digunakan adalah dengan memasang bola pada rangka besi yang sudah dilas sedemikian rupa agar dapat memuat bola tersebut dengan pas. Bola yang digunakan adalah bola yoga yang dapat menerima beban dan gaya yang berat tanpa harus takut bola akan meledak. 

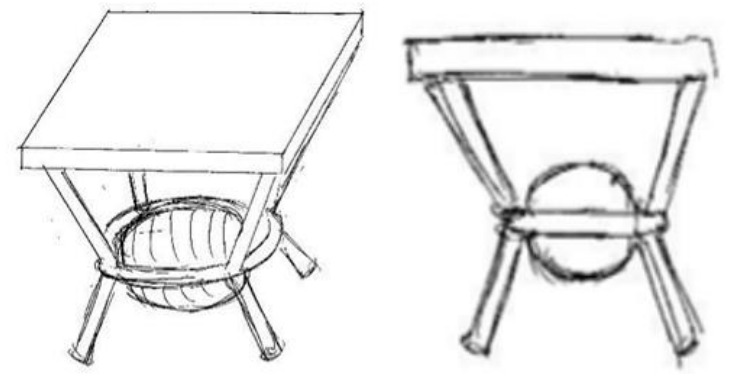

Gambar 6. Konsep Kelima (Desain E) Sumber: Penulis, 2020

Konsep alternatif keenam (Desain F) dapat dilihat pada Gambar 7. Pada mekanisme kinestetiknya memakai pedal yang dapat diputar 360 derajat yang dilas pada bearing yang sudah dipasangkan pada rangka meja. Rangka meja memakai batang besi untuk meningkatkan durabilitas meja. Papan meja dibuat setengah lingkaran.
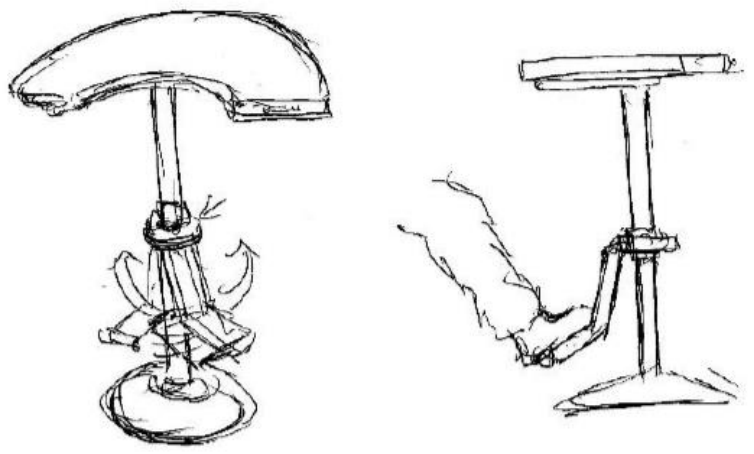

Gambar 7. Konsep Keenam (Desain F) Sumber: Penulis, 2020

Konsep alternatif terakhir yaitu ketujuh (Desain G) dapat dilihat pada Gambar 8. Bagian kaki menggunakan pedal seperti pada mesin jahit atau pedal mobil dengan menggunakan pegas di bagian bawahnya.
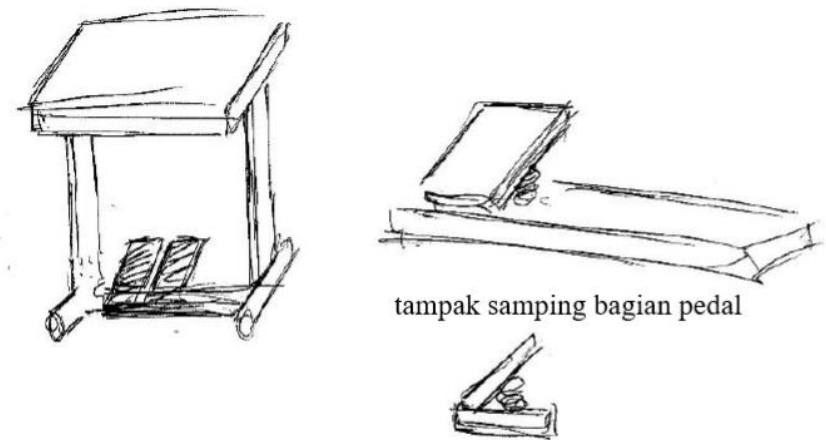

Gambar 8. Konsep Ketujuh (Desain G) Sumber: Penulis, 2020

Data antropometri yang digunakan adalah data antropometri orang Indonesia usia 9-11 tahun yang diakses dari website www.antropometriindonesia.org (n.d). Tinggi meja menggunakan data (1) ukuran tinggi siku dalam posisi duduk ditambah dengan data (2) tinggi popliteal orang duduk (Gambar 9). Data yang digunakan merupakan data pria dan wanita dan diambil dengan persentil 50\%. Untuk dimensi tinggi siku posisi duduk dengan persentil 50\% adalah sebesar $15,91 \mathrm{~cm}$, sedangkan untuk dimensi tinggi popliteal persentil $50 \%$ adalah sebesar $35,01 \mathrm{~cm}$. 
Hasil akhir untuk tinggi meja adalah sebesar 50,92 cm, tinggi tersebut akan dibulatkan menjadi $55 \mathrm{~cm}$ sebagai allowance yaitu ketebalan papan meja bagian atas dan ditambahkan $20 \mathrm{~cm}$ lagi sebagai fitur adjustable maksimal ketinggian meja menjadi $70 \mathrm{~cm}$. Desain A hingga F memiliki allowance untuk pergerakan kaki setinggi $20 \mathrm{~cm}$ dari tanah, sedangkan Desain $\mathrm{G}$ rata dengan tanah. Dimensi pedal dirancang agar maksimum lebar kaki ditambah sepatu bisa nyaman di pedal, yaitu $15 \mathrm{~cm}$.
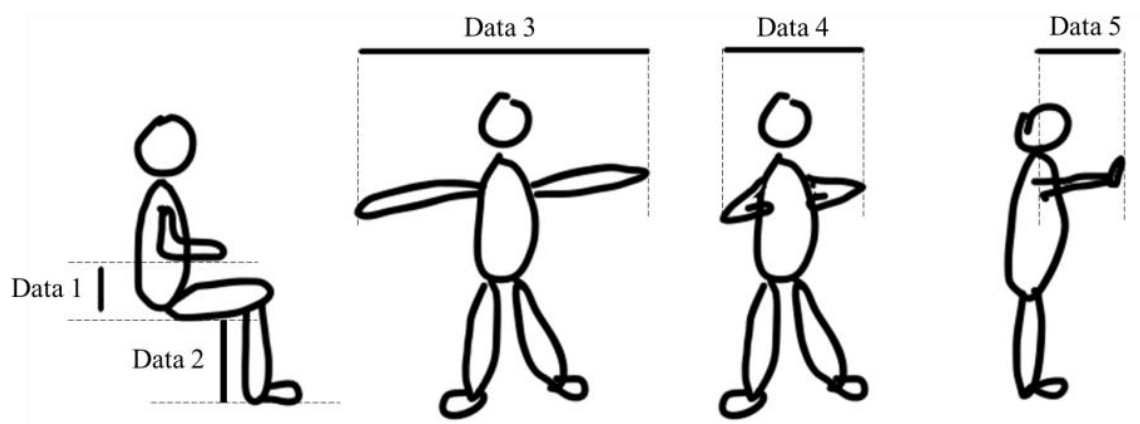

Gambar 9. Data Antropometri yang Digunakan

Sumber: Penulis, 2020

Penentuan panjang meja memerlukan ukuran jangkauan tangan (data 3 dan data 4 pada Gambar 9). Diasumsikan bahwa ukuran panjang meja harus berada diantara kedua dimensi yang ditentukan, dalam artian lain, ukuran panjang meja tidak boleh lebih dari jangkauan tangan ke samping dan tidak kurang dari panjang rentangan siku. Dimensi panjang jangkauan tangan ke samping dengan persentil $50 \%$ adalah $128,48 \mathrm{~cm}$, dan panjang rentangan siku adalah sebesar $65,48 \mathrm{~cm}$. Ukuran yang cocok untuk sebuah meja belajar minimal $70 \mathrm{~cm}$, hal ini dikarenakan agar siku dapat diletakkan di permukaan meja dan memiliki area gerak yang lebih, serta dengan panjang meja yang lebih kecil dari jangkauan tangan ke samping akan mempermudah penjangkauan barang di meja belajar ini. Jangkauan tangan ke depan (data 5) untuk persentil 50\% adalah $58,14 \mathrm{~cm}$. Pada perancangan meja kinestetik ini, digunakan lebar meja sebesar $50 \mathrm{~cm}$ dengan pertimbangan bahwa data ukuran jangkauan tangan adalah lebar maksimal.

Tahap berikutnya adalah pemilihan konsep dari ketujuh desain alternatif yang telah dibuat. Tabel matriks digunakan untuk membantu dalam pemilihan konsep desain seperti yang diuraikan dalam Ulrich dan Eppinger (2016). Langkah pertama adalah memilih desain yang akan digunakan sebagai referensi, dalam penelitian ini, dipilih desain B sebagai desain referensi. Langkah berikutnya adalah pemberian skor, yaitu diberi angka 0 jika sama, tanda - jika lebih buruk, dan tanda + jika lebih baik. Setelah itu dijumlahkan skor tiap desain menjadi total skor, kemudian diranking berdasarkan yang terbesar rankingnya.

Tabel 1. Matriks Pemilihan Konsep

\begin{tabular}{|l|c|c|c|c|c|c|c|}
\hline \multirow{2}{*}{ Kriteria } & \multicolumn{7}{|c|}{ Desain } \\
\cline { 2 - 8 } & $\mathrm{A}$ & $\mathrm{B}$ (referensi) & $\mathrm{C}$ & $\mathrm{D}$ & $\mathrm{E}$ & $\mathrm{F}$ & $\mathrm{G}$ \\
\hline mudah dibongkar & 0 & 0 & - & 0 & - & - & 0 \\
\hline mudah diproduksi & 0 & 0 & 0 & 0 & - & 0 & 0 \\
\hline mudah dipindahkan & 0 & 0 & 0 & 0 & 0 & 0 & 0 \\
\hline ruang gerak & + & 0 & - & + & - & + & + \\
\hline daya tahan & 0 & 0 & 0 & 0 & 0 & 0 & 0 \\
\hline estetika & + & 0 & - & + & 0 & 0 & - \\
\hline Total + & 2 & 0 & 0 & 2 & 0 & 1 & 1 \\
\hline Total - & 0 & 0 & 3 & 0 & 3 & 1 & 1 \\
\hline Total Score & 2 & 0 & -3 & 2 & -3 & 0 & 0 \\
\hline Rank & 1 & 4 & 6 & 1 & 6 & 4 & 3 \\
\hline Lanjutkan? & Ya & Tidak & Tidak & Ya & Tidak & Tidak & Tidak \\
\hline
\end{tabular}


Desain A dan desain D terpilih untuk menjadi kandidat yang digunakan untuk dikembangkan pada tahap berikutnya. Tinggi meja dapat disesuaikan, dalam arti tinggi meja dapat diatur untuk desain meja kinestetik agar dapat digunakan dalam posisi duduk maupun berdiri. Bagian kinestetik hanya digunakan saat posisi siswa duduk.

Sebelum pembuatan prototype, langkah pertama adalah membuat gambar teknik untuk meja kinestetik desain terpilih (desain A dan D) pada Gambar 10. Prototype Alpha dibuat menggunakan 3D printing dengan menggunakan skala. Karena keterbatasan dana, prototype 3D printing hanya membuat desain D yang dapat dilihat pada Gambar 11.
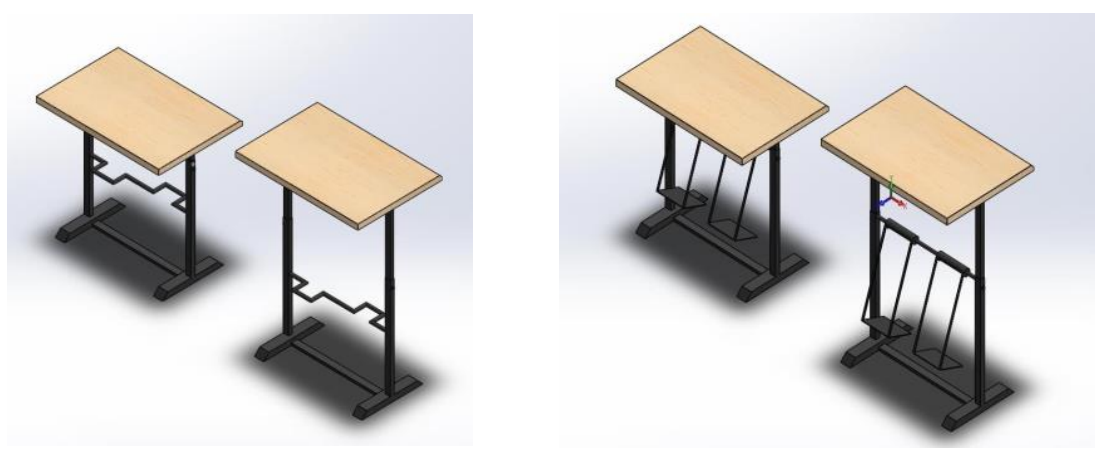

Gambar 10. Gambar Teknik Meja Desain A dan D Sumber: Penulis, 2020

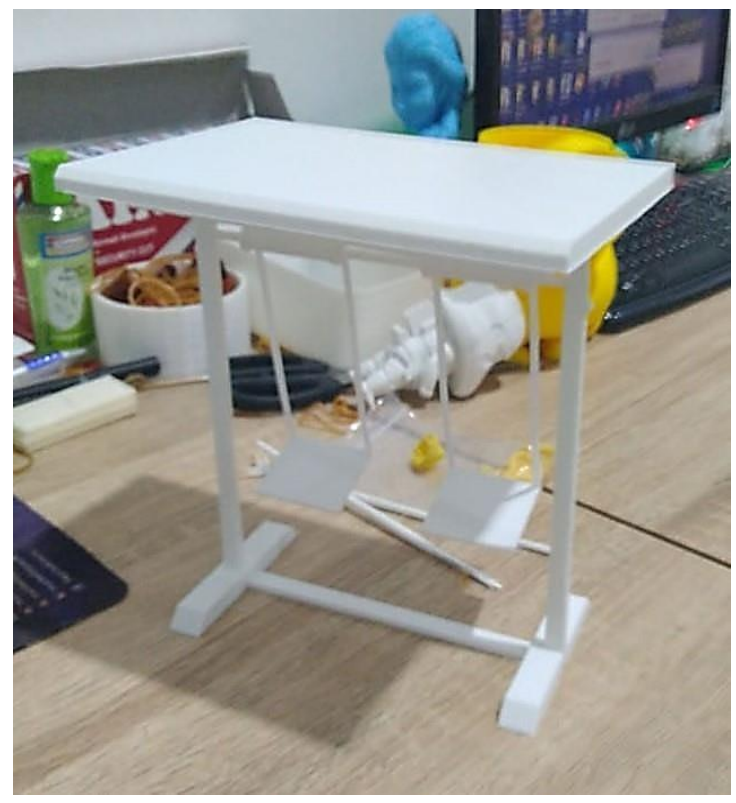

Gambar 11. Prototype Alpha Menggunakan 3D Printing Sumber: Penulis, 2020

Setelah membuat model 3D printing maka dilanjutkan ke tahap selanjutnya yakni membuat prototype beta dengan panjang dan lebar papan seluas $70 \mathrm{~cm} \times 50 \mathrm{~cm}$ dan tinggi meja dengan posisi terendah $55 \mathrm{~cm}$ dan posisi tertinggi $75 \mathrm{~cm}$. Dalam membuat rangka meja menggunakan besi dengan mekanisme pedal menggunakan bearing yang disambung dan dilas dari ujung ke ujung tiang rangka, meja ini dapat di atur tinggi rendahnya. Papan meja menggunakan triplek tebal. Prototype ini akan digunakan untuk di uji coba oleh anak-anak sekolah dasar.

Tahap selanjutnya dalam pembuatan produk ini adalah tahap pengujian dan perbaikan. Tahap ini adalah tahap evaluasi prototype dan mencari cara untuk mencari hal yang dapat meningkatkan produk akhir. Gambar 12 menunjukan saat proses pembuatan prototype beta dengan foto seorang anak SD mencoba prototype tersebut. Prototype beta yang akan digunakan sebagai uji coba dapat dilihat pada Gambar 13. 

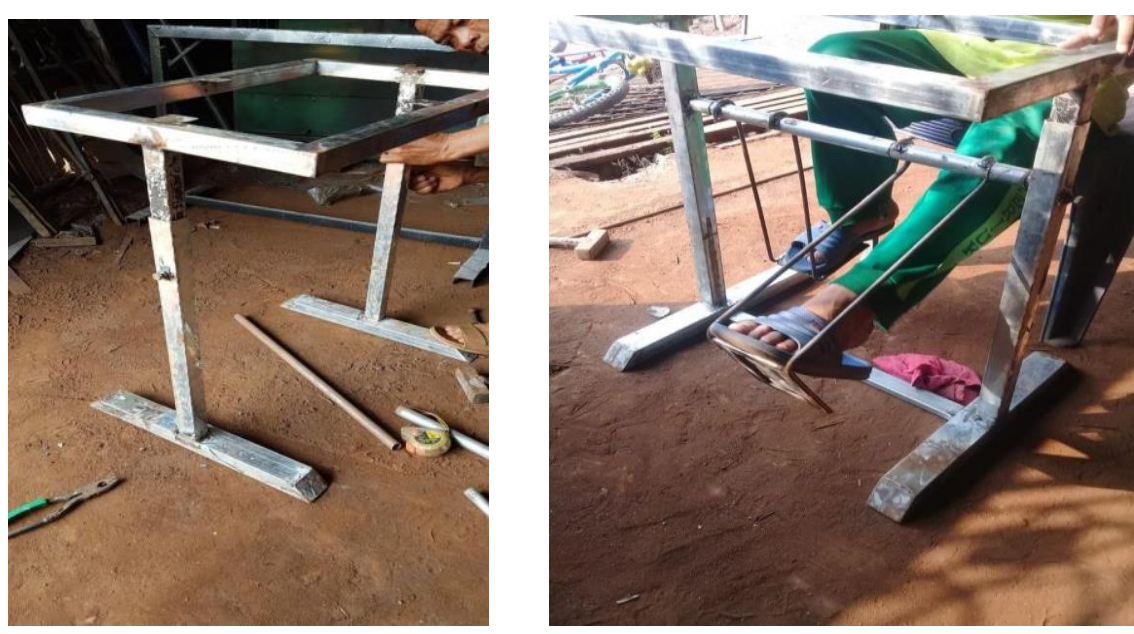

Gambar 12. Prototype Beta Saat Sedang Diproduksi dan Dicoba Sumber: Penulis, 2020
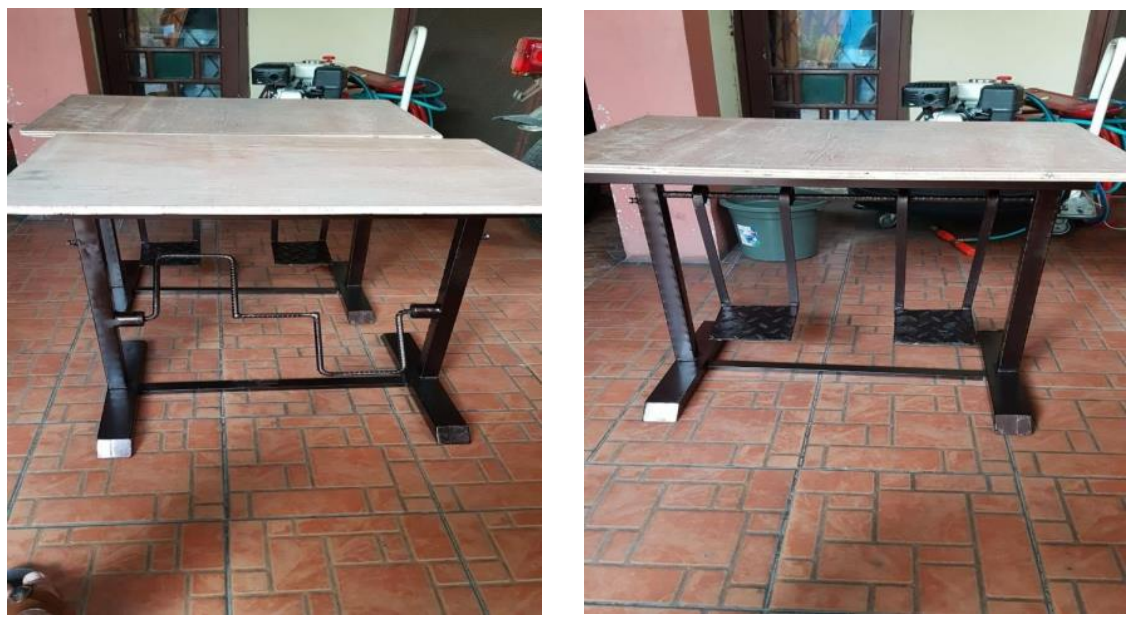

Gambar 13. Prototype Beta Desain A (kiri) dan Desain D (kanan)

Sumber: Penulis, 2020

Pada saat prototype beta kedua desain diuji coba pada 40 siswa SD dan ditanyakan menggunakan kuesioner yang dipandu oleh peneliti, hasilnya adalah konsep desain D terpilih dengan persentase $72 \%$ menyukai meja tersebut.

Tahap berikutnya adalah pembuatan produk akhir berdasarkan perbaikan prototype beta untuk desain terpilih (desain D). Hasil uji coba menunjukan tinggi pedal ayunan terlalu tinggi untuk siswi sehingga pedal diturunkan, sehingga tinggi pedal dari tanah yang tadinya $20 \mathrm{~cm}$ menjadi 10 $\mathrm{cm}$. Produk akhir dapat dilihat pada Gambar 14. 

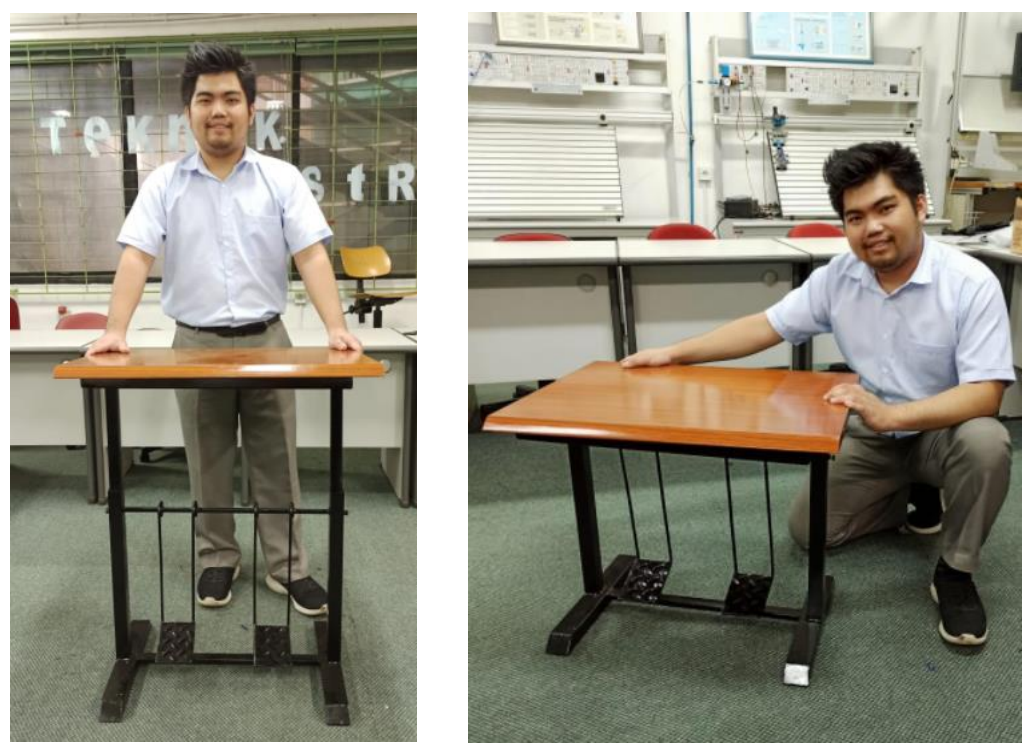

Gambar 14. Produk Akhir Meja Kinestetik Posisi Untuk Digunakan Berdiri (kiri) dan Posisi Digunakan duduk (kanan)

Sumber: Penulis, 2020

\section{Kesimpulan dan Saran}

Tahapan perencanaan dan perancangan meja kinestetik ergonomis untuk anak Sekolah Dasar telah berhasil menghasilkan produk meja sesuai tujuan. Meja kinestetik ini sedang diajukan untuk mendapatkan Hak Desain Industri sejak Desember 2019. Meja ini direncanakan untuk dapat diproduksi setelah mendapatkan HKI dengan menggandeng masyarakat dan usaha kecil menengah (UKM).

Saran untuk penelitian selanjutnya adalah mengembangkan fitur lainnya untuk dapat ditambahkan pada meja kinestetik ini seperti pengembangan bagian papan meja, penambahan laci penyimpanan, penambahan tempat alat tulis di meja. Penelitian untuk usia selain SD juga diperlukan untuk membantu pembelajar yang memiliki gaya belajar kinestetik.

\section{Ucapan Terima Kasih}

Ucapan terima kasih ditujukan kepada Universitas Pelita Harapan karena telah mendanai penelitian ini dengan nomor penelitian P-507-S/FaST/VIII/2019 dan pengajuan HKI meja kinestetik melalui LPPM UPH.

\section{Daftar Pustaka}

Begel, A., Garcia, D. D. \& Wolfman, S. A. (2004), Kinesthetic Learning in The Classroom, ACM SIGCSE Bulletin, 36(1), 183, doi:10.1145/1028174.971367.

Chen, J. Q., Moran, S. \& Gardner, H. (2009), Multiple Intelligences Around The World, John Wiley \& Sons.

Dudung, Agus (2012), Merancang Produk, Jakarta: Penerbit PT. Remaja Rosda Karya.

Data Antropometri Indonesia (n.d)., www.antropometriindonesia.org. Diakses pada hari Selasa, 9 Juli 2019 Pk. 12.00 WIB.

Fleming, N. D., and Mills, C. (1992), Helping Students Understand How They Learn. The Teaching Professor, 7(4), Madison, Wisconsin, USA: Magma Publications.

Gilakjani, A. P. (2011), Visual, Auditory, Kinaesthetic Learning Styles and Their Impacts on English Language Teaching, Journal of Studies in Education,2(1), 104. doi:10.5296/jse.v2i1.1007 
Ginting, Rosnani (2010), Perancangan Produk, Yogyakarta: Graha Ilmu.

Hartono, N., Laurence, Ardian, J. (2018), Integration of Design for Environment Principles and Guidelines into Study Desk Design. IOP Conf. Series: Earth and Environmental Science 195. doi:10.1088/1755-1315/195/1/012073.

Hartono, N., Christiani, A., Larasati, C.K. (2019), Modular Furniture Made From Corrugated Box Waste Using Design For Environment Guidelines, Journal of Environmental Science and Sustainable Development 2(1). https://doi.org/10.7454/jessd.v2i1.26.

Human Factors/Ergonomics (HF/E). (n.d.), https://iea.cc/what-is-ergonomics/, diakses pada hari Selasa, 9 Juli 2019 Pk. 09.00 WIB.

IVL Swedish Environmental Research Institute (n.d.), https://www.ivl.se/english/startpage/pages/focus-areas/environmental-engineering-andsustainableproduction/lca/eps.html, diakses pada hari Selasa, 9 Juli 2019 Pk. 17.00 WIB.

KBBI Daring. (n.d.), https://kbbi.kemdikbud.go.id/, diakses pada hari Selasa, 9 Juli 2019 Pk. 08.00 WIB.

Kotler, P., et.al. (2018), Marketing Management: an Asian Perspective, Pearson.

Laurence, Hartono, N., Setiawan, C.A. (2018), Prototype Design of Chicken Meat Cutting Tool. MATEC Web of Conference 218, EDP Sciences. https://doi.org/10.1051/matecconf/201821804003

Leasa, M., Corebima, A.D., Ibrohim, Suwono, H. (2017), Emotional Intelligence among Auditory, Reading, and Kinesthetic Learning Styles of Elementary School Students in Ambon - Indonesia, International Electronic Journal of Elementary Education 10 (1)

Nasution, A H. Prasetyawan, Y. (2008), Perencanaan dan Pengendalian Produksi, Yogyakarta : Graha Ilmu.

Rahman, A., \& Ahmar, A. S. (2017), Relationship Between Learning Styles and Learning Achievement in Mathematics Based on Genders, World Transactions on Engineering and Technology Education, 15(1), doi:10.26858/wtetev15i1y2017p7477

Tahid, Suwarno, dan Nurcahyaeni, Yunita Dwi. (2007), Konsep Teknologi dalam Pengembangan Produk Industri, Jakarta: Putra Grafika

Ulrich, K. T., \& Eppinger, S. D. (2016), Product Design and Development, New York, NY: McGraw-Hill Education.

Vaishnav, R.S. (2013), Learning Style and Academic Achievement of Secondary School Students, Voice of Research 1 (4)

Wignjosoebroto, Sritomo. Ergonomi (2008), Studi Gerak dan Waktu, Surabaya: Guna Widya, 